\title{
Coronavirus (COVID-19) and its Relationship with Ocular Surface
}

\author{
Koronavirüs (COVID-19) ve Oküler Yüzey ile iliş̧kisi
}

(i) Cansu EKINCII, io Mehmet Hakan ÖZDEMİR

Bezmialem Vakıf University Faculty of Medicine, Department of Ophthalmology, İstanbul, Turkey

\section{ABSTRACT}

An outbreak in China's Wuhan city in December 2019, characterized by unidentified pneumonia, leading to severe acute respiratory distress syndrome has begun. The cause of the outbreak has been detected as Severe acute respiratory syndrome-related coronavirus-2 (SARS-CoV-2), which is a new coronavirus and due to its rapid spread in a short time, it has been announced as a pandemic in terms of public health by the World Health Organization. The virus is transmitted mainly by direct contact with the secretions of patients and inhalation of virus-containing micro-droplets. The transmission of the virus via the ocular route is a controversial issue and there are limited number of studies in the literature. Follicular conjunctivitis may be one of the ocular manifestations of the disease and even if there is no concomitant conjunctivitis, it is very important for the ophthalmologists and healthcare professionals to take preventive measures. In this review, the relationship of SARSCoV-2 with ocular surface findings was evaluated in the light of the literature.

Keywords: Ocular surface, conjunctivitis, tear, COVID-19

\section{ÖZ}

Çin'in Wuhan şehrinde Aralık 2019'da nedeni belirlenemeyen pnömoni ile karakterize, ciddi akut solunum sıkıntıcı sendromuna yol açan bir salgın başlamıştır. Salgının etkeninin yeni bir koronavirüs olan şiddetli akut solunum yetersizliği sendromu-2 (SARS-CoV-2) olduğu saptanıp kısa bir süre içinde hızla yayılım göstermesiyle Dünya Sağlık Örgütü tarafından halk sağlığı açısından acil durum olan pandemi olarak ilan edilmiştir. Virüs başlıca hastaların sekresyonları ile doğrudan temas ile virüs içeren mikrodamlacıkların inhalasyonu ile bulaşmaktadır. Virüsün oküler yol ile bulaşması ise tartışmalı bir konu olup literatürde sınırlı sayıda çalışma mevcuttur. Foliküler konjonktivitin hastalığın oküler bulgularından biri olabileceği ve eşlik eden konjonktivit olmasa dahi özellikle oftalmologların ve sağlık çalışanlarının koruyucu önlemler almaları oldukça önem taşımaktadır. Bu derlemede SARSCoV-2'nin oküler yüzey bulguları ile ilişkisi literatür eşliğinde değerlendirilmiştir.

Anahtar Sözcükler: Oküler yüzey, konjonktivit, gözyaşı, COVİD-19

\section{General Information}

Coronaviruses are enveloped, positive stranded RNA viruses and are members of the Coronavirinae subfamily within the Coronaviridae family. The name coronavirus comes from the Latin word "corona" which means "crown" because the characteristic spiny protrusions on its envelope create a crown-like appearance (1). It is known that coronaviruses infect various mammals and birds, and with the ability to mutate, they can acquire the characteristic of zoonotic pathogens that facilitate their transition from animal to human $(2,3)$. Four types of coronaviruses known to infect humans have been identified (HCoV-229E, -NL63, -OC43, and -HKU1). The oldest information about the endemic human coronavirus goes back to the 1960s. severe acute respiratory distress (SARS) and Middle East respiratory syndrome (MERS) coronaviruses, which caused epidemics in 2003 and 2012, are of animal origin

Cite this article as: Ekinci C, Özdemir MH. Coronavirus (COVID-19) and its Relationship with Ocular Surface. Bezmialem Science. 2021;9(Supplement 1):74-77. 
and can cause fatal respiratory failure in humans (4-7). Finally, a severe pneumonia of unknown cause, which started in Wuhan, China in December 2019, rapidly spread all over the world. In January 2020, it was reported that the cause of this epidemic was a new coronavirus (SARS-CoV-2) and was recognized as an international public health emergency by the World Health Organization (WHO). In February 2020, WHO named the new coronavirus disease (COVID-19) (8-10).

Coronaviruses bind to the respiratory or intestinal epithelium, causing changes and death in host cells. Its clinical outcomes are highly variable, and while the majority of cases show asymptomatic or mild symptoms, severe respiratory failure and death may result in those over 60 years of age and those with comorbid diseases such as hypertension, cardiovascular disease, chronic lung disease or cancer. The incubation period is 2-14 days, and typical signs and symptoms are high fever, dry cough, shortness of breath, myalgia, fatigue, and bilateral ground-glass appearance on chest computed tomography (CT) $(11,12)$. Coronaviruses can also cause ocular and gastrointestinal system symptoms outside of the respiratory system. The main modes of transmission are by airborne microdroplets as a result of close contact with patients, direct contact with the patient or contaminated objects, and fecal-oral route. Micro-droplets that spread into the air by sneezing, coughing or exhaling can enter the body through the mouth, nasal mucosa or conjunctiva. Therefore, WHO stated that healthcare professionals who are in contact with suspected (COVID-19) patients should protect their mouth, nose and eyes with glasses, masks and visors (13).

\section{COVID-19 and Ocular Surface Findings}

It has been shown that respiratory tract viruses can cause ocular complications in infected patients and even cause respiratory tract infections later on. This situation creates serious concern especially for ophthalmologists. In 2004, HCoV-NL63 type $\mathrm{CoV}$ was detected for the first time in a 7-month-old baby who was found to have bronchiolitis and conjunctivitis in the SARS coronavirus epidemic (14). In a retrospective study conducted in France during the same epidemic period, when the data of children infected with HCoV-NL63 between 2000 and 2003 were examined, it was found that $17 \%$ of the patients had conjunctivitis (15). In 2004, Loon et al. (16) applied polymerase chain reaction (PCR) to early tear samples of 36 suspected SARS cases (eight of them were later confirmed by serology, the remaining patients were serologically negative) consisting of healthcare workers. In 3 of eight cases (37.5\%), viruses were detected by PCR test of tears, in one of them, virus RNA could not be detected in feces and nasopharynx samples, but was detected only at eye tear. They stated that especially ophthalmologists and healthcare professionals work close to the eyes of patients, and because the virus is detected in the early period of the infection at the eye tear, and devices that are constantly used such as spectacle frames and applanation tonometers can be potential sources of contamination (16). On the contrary, in the study conducted by Chan et al. (17) in 2004, nasopharynx, feces, eye tear samples and conjunctival swabs were taken from 17 patients whose diagnosis was confirmed by serology. The nasopharynx and feces samples were PCR+ in 5 of them, but in eye tear and conjunctival swab samples, no virus genetic material detected by PCR. The authors explained this result for 3 possible reasons. The first is that the specificity of the PCR test is very high and the sensitivity is low, so the result may be false negative. It was stated that to increase sensitivity, more samples should be taken from more patients. Another reason is that since the virus is in body secretions for a limited time, negative results can be obtained due to sampling during the window period. Finally, they stated that the virus may not be present in eye tears (17).

Today, there is quite a limited amount of data regarding the relationship of COVID-19, which causes pandemic, with ocular involvement. In cases with symptoms, mild follicular conjunctivitis, hyperemia in the bulbar conjunctiva, epiphora, chemosis or mild eyelid edema are observed $(13,18)$. In a report published in The Lancet, Guangfa Wang, who had studies on pneumonia, during his examination, in Wuhan, attributed himself to be infected because of not wearing protective glasses despite wearing an N95 mask. It has been reported that Wang developed pneumonia after conjunctivitis symptoms developed (19). In addition, ophthalmologist Dr. Li Wenliang infected and died as a result of contact with a patient. In a study, Xia et al. (20) took two samples from 30 COVID-19 patients, they examined eye tear, conjunctival swab and saliva samples and detected the virus by PCR only in 2 samples taken from a patient with conjunctivitis. The authors emphasized the importance of protecting with protective glasses from the patients with no signs of conjunctivitis, as they are at risk for transmission by droplets, although the virus is detected in very low levels at the eye tears, even if the virus is not present at ocular surface of the patients examined by ophthalmologists at close range (20). Similarly, in the study conducted by Seah et al. (21), a total of 64 eye tear samples were taken simultaneously with nasopharynx swab samples from 17 COVID-19 patients between the $3^{\text {rd }}$ and $20^{\text {th }}$ days from the onset of the findings, with an interval of one week, and evaluated with the viral culture and PCR, but no virus was shown in eye tears. Although the detection rates of the virus at eye tear are low in the literature, in one case reported, the virus was detected in the conjunctival swab on the $13^{\text {th }}$ day from the onset of the findings, and the conjunctival swab sample was found to be PCR+ until the $19^{\text {th }}$ day (18). In another case, conjunctivitis accompanying respiratory tract infection was present and the conjunctival swab PCR result was found to be positive until the $27^{\text {th }}$ day of the disease, although the nasopharynx swab result was negative. This suggests that the virus can remain in the conjunctiva for a longer time (22).

Baig et al. (24) performed retinal examinations of 12 patients, whose diagnosis was confirmed by PCR or antibody detection, by using optical coherence tomography (OCT) device between 11 and 33 days after the onset of COVID-19 symptoms, and reported retinal changes associated with COVID-19 for the first time. They detected hyperreflective lesions in both eyes, ganglion cells and inner plexiform layer, particularly in the papillomacular nerve bundle in all patients. In addition, the presence of cotton wool spots and microhemorrhages at the level of the vascular 
arcade in the fundus examination of four patients suggests that the disease may be a microvasculopathy.

Although there are concerns about COVID-19 infection acquired through ocular transmission, the underlying mechanism has not been fully clarified. It is emphasized that the virus infects host cells via angiotensin converting enzyme-2 (ACE-2) receptor and transmembrane protease serine-2 (TMPRSS-2), as in SARS $(23,24)$. A study has shown that ACE-2 and TMPRSS-2 production is more dominant in corneal limbal cells rather than conjunctiva, but the contribution of this to the systemic circulation of the virus is to be discussed $(13,25,26)$. In addition, due to the dynamism of the eye tear film, it is thought that the transition of eye tears to the nasal cavity by the canaliculi reduces the duration of the ocular surface and the risk of transmission. In patients with lacrimal drainage obstruction, on the contrary, it is stated that the duration of the virus on the ocular surface will be prolonged and may cause periocular skin contamination due to accompanying epiphora (27-29).

As a result, studies on ocular findings caused by SARS-CoV-2 in humans are increasing. As the ocular effects and details of SARS-CoV-2 are determined, possible prevention measures and treatment options will become clearer.

Peer-review: Externally peer reviewed.

\section{Authorship Contributions}

Concept: C.E., Design: C.E., M.H.Ö., Data Collection or Processing: C.E., Analysis or Interpretation: C.E., M.H.Ö., Literature Search: C.E., Writing: C.E.

Conflict of Interest: No conflict of interest was declared by the authors.

Financial Disclosure: This work was supported by Gilead Sciences.

\section{References}

1. Madhugiri R, Fricke M, Marz M, Ziebuhr J. Coronavirus cis-acting RNA elements. Adv Virus Res 2016;96:127-63.

2. Salata C, Calistri A, Parolin C, Palù G. Coronaviruses: A paradigm of new emerging zoonotic diseases. Pathog Dis 2019;77:1-5.

3. Woo PC, Lau SK, Huang Y, Yuen KY. Coronavirus diversity, phylogeny and interspecies jumping. Exp Biol Med (Maywood) 2009;234:1117-27.

4. Habibzadeh P, Stoneman EK. The Novel Coronavirus: A Bird's Eye View. Int J Occup Environ Med 2020;11:65-71.

5. Su S, Wong G, Shi W, Liu J, Lai ACK, Zhou J, et al. Epidemiology, genetic recombination, and pathogenesis of coronaviruses. Trends Microbiol 2016;24:490-502.

6. Seah I, Agrawal R. Can the coronavirus disease 2019 (COVID-19) affect the eyes? A review of coronaviruses and ocular implications in humans and animals. Ocul Immunol Inflamm 2020;28:391-5.

7. Corman VM, Muth D, Niemeyer D, Drosten C. Hosts and sources of endemic human coronaviruses. Adv Virus Res 2018;100:163-88.
8. Zhu N, Zhang D, Wang W, Li X, Yang B, Song J, et al. A novel coronavirus from patients with pneumonia in China, 2019. N Engl J Med 2020;382:727-33.

9. World Health Organization. Novel coronavirus (2019-nCoV) situation report-1.21 January 2020. Available from: https://www.who. int/docs/default-source/coronaviruse/situation-reports/20200121sitrep-1-2019-ncov.pdf?sfvrsn=20a99c10_4\%203.

10. World Health Organization. Report of the WHO-China joint mission on coronavirus disease 2019 (COVID-19). Available from: https://www.who.int/docs/default-source/coronaviruse/who-chinajoint-mission-on-covid-19-final-report.pdf.

11. Huang C, Wang Y, Li X, Ren L, Zhao J, Hu Y, et al. Clinical features of patients infected with 2019 novel coronavirus in Wuhan, China. Lancet 2020;395:497-506.

12. Chen N, Zhou M, Dong X, Qu J, Gong F, Han Y, et al. Epidemiological and clinical characteristics of 99 cases of 2019 novel coronavirus pneumonia in Wuhan, China: a descriptive study. Lancet 2020;395:507-13.

13. Napoli PE, Nioi M, d'Aloja E, Fossarello M. The ocular surface and the coronavirus disease 2019: Does a dual 'ocular route' exist? J Clin Med 2020;9:1269.

14. van der Hoek L, Pyrc K, Jebbink MF, Vermeulen-Oost W, Berkhout $\mathrm{RJ}$, Wolthers $\mathrm{KC}$, et al. Identification of a new human coronavirus. Nat Med 2004;10:368-73.

15. Vabret A, Mourez T, Dina J, van der Hoek L, Gouarin S, Petitjean J, et al. Human coronavirus NL63, France. Emerg Infect Dis 2005;11:1225-9.

16. Loon SC, Teoh SC, Oon LL, Se-Thoe SY, Ling AE, Leo YS, et al. The severe acute respiratory syndrome coronavirus in tears. $\mathrm{Br} \mathrm{J}$ Ophthalmol 2004;88:861-3.

17. Chan WM, Yuen KS, Fan DS, Lam DS, Chan PK, Sung JJ. Tears and conjunctival scrapings for coronavirus in patients with SARS. Br J Ophthalmol 2004;88:968-9.

18. Chen L, Liu M, Zhang Z, Qiao K, Huang T, Chen M, et al. Ocular manifestations of a hospitalised patient with confirmed 2019 novel coronavirus disease. Br J Ophthalmol 2020;104:748-51.

19. Lu CW, Liu XF, Jia ZF. 2019-nCoV transmission through the ocular surface must not be ignored. Lancet 2020;395:39.

20. Xia J, Tong J, Liu M, Shen Y, Guo D. Evaluation of coronavirus in tears and conjunctival secretions of patients with SARS-CoV-2 infection. J Med Virol 2020;92:589-94.

21. Seah IYJ, Anderson DE, Kang AEZ, Wang L, Rao P, Young BE, et al. Assessing viral shedding and infectivity of tears in coronavirus disease 2019 (COVID-19) patients. Ophthalmology 2020;127:977-9.

22. Colavita F, Lapa D, Carletti F, Lalle E, Bordi L, Marsella P, et al. SARS-CoV-2 isolation from ocular secretions of a patient with COVID-19 in Italy with prolonged viral RNA detection. Ann Intern Med 2020;173:242-3.

23. Fodoulian L, Tuberosa J, Rossier D, Boillat M, Kan C, Pauli V, et al. SARS-CoV-2 receptors and entry genes are expressed in the human olfactory neuroepithelium and brain. iScience 2020;23:101839.

24. Baig AM, Khaleeq A, Ali U, Syeda H. Evidence of the COVID-19 
virus targeting the CNS: Tissue distribution, host-virus Interaction, and proposed neurotropic mechanisms. ACS Chem Neurosci 2020;11:995-8.

25. Sungnak W, Huang N, Bécavin C, Berg M, Queen R, Litvinukova $\mathrm{M}$, et al. SARS-CoV-2 entry factors are highly expressed in nasal epithelial cells together with innate immune genes. Nat Med 2020;26:681-7.

26. Ma D, Chen CB, Jhanji V, Xu C, Yuan XL, Liang JJ, et al. Expression of SARS-CoV-2 receptor ACE2 and TMPRSS2 in human primary conjunctival and pterygium cell lines and in mouse cornea. Eye (Lond) 2020;34:1212-9.
27. Napoli PE, Nioi M, Mangoni L, Gentile P, Braghiroli M, d'Aloja E, et al. Fourier-domain OCT imaging of the ocular surface and tear film dynamics: A review of the state of the art and an integrative model of the tear behavior during the inter-blink period and visual fixation. J Clin Med 2020;9:668.

28. Sun Y, Liu L, Pan X, Jing M. Mechanism of the action between the SARS-CoV S240 protein and the ACE2 receptor in eyes. Int. J Ophthalmol 2006;6:783-6.

29. Sun K, Gu L, Ma L, Duan Y. Atlas of ACE2 gene expression reveals novel insights into transmission of SARS-CoV-2. Heliyon 2021;7:05850. 